\title{
In-situ X-ray absorption study of ceria-supported Pd-Cu nanoparticles for oxygen-enhanced water gas shift
}

Junichiro Kugai $^{1, \dagger, * *}$, Jeffrey T. Miller $^{2}$, Elise B. Fox ${ }^{3}$, Chunshan Song ${ }^{1 *}$

${ }^{1}$ Clean Fuels and Catalysis Program, EMS Energy Institute, and Department of Energy and Mineral Engineering, The Pennsylvania State University, 209 Academic Projects Building, University Park, PA 16802, USA

${ }^{2}$ School of Chemical Engineering, Purdue University, 480 Stadium Mall Drive, West Lafayette, IN 47907-2100

${ }^{3}$ Materials Science \& Technology, Savannah River National Laboratory, Aiken, SC 29808, USA

* Corresponding author: Prof. Chunshan Song, E-mail: csong@psu.edu; Phone: 814-863-4466; Fax: 814-865-3573

${ }^{* *}$ Second corresponding author: Dr. Junichiro Kugai, E-mail: jkugai@ kobe-kosen.ac.jp; Phone: +81-78-795-3252; Fax: +81-78-795-3314

${ }^{\dagger}$ Current address: Department of Applied Chemistry, Kobe City College of Technology, 8-3 Gakuen-higashimachi, Nishi-ku, Kobe, Hyogo 565-0871, Japan 


\begin{abstract}
The detailed structure of bimetallic $\mathrm{Pd}-\mathrm{Cu}$ on various $\mathrm{CeO}_{2}$ and $\mathrm{Al}_{2} \mathrm{O}_{3}$ supports were investigated by X-ray absorption technique in-situ in hydrogen and WGS conditions. No indication of the neighboring Pd atoms in both $\mathrm{Pd}-\mathrm{K}$ edge and $\mathrm{Cu}-K$ edge EXAFS fittings showed that $\mathrm{Pd}$ is highly dispersed in the lattice of metallic $\mathrm{Cu}$. The $\mathrm{Cu}-\mathrm{Cu}$ bond distance was markedly shortened by alloying with $\mathrm{Pd}$ and correlated to decrease of coordination number, which reflects particle size. A higher coordination number for Pd-Cu than that for $\mathrm{Cu}-\mathrm{Cu}$ on $\mathrm{Al}_{2} \mathrm{O}_{3}$ support suggested that $\mathrm{Pd}$ is in the interior of the nanoparticles on $\mathrm{Al}_{2} \mathrm{O}_{3}$ while these coordination numbers were close on $\mathrm{CeO}_{2}$ support indicating a uniform distribution of $\mathrm{Pd}$ and $\mathrm{Cu}$ atoms. The $\mathrm{CO}$ shift activity was not simply correlated to the $\mathrm{Cu}-\mathrm{Cu}$ bond distance or particle size, but the high activity of $\mathrm{Pd}-\mathrm{Cu} / \mathrm{CeO}_{2}$ was attributed to surface $\mathrm{Pd}$ interacting with $\mathrm{Cu}$ on $\mathrm{CeO}_{2}$ surface.
\end{abstract}

Key wards: Extended X-ray absorption fine structure (EXAFS), $\mathrm{CeO}_{2}$-supported $\mathrm{Pd}-\mathrm{Cu}$, Bimetallic catalyst, Pd-Cu alloy, Oxygen-enhanced Water Gas Shift (OWGS)

\title{
1. Introduction
}

Water gas shift (WGS) is one of the key steps in fuel processing for $\mathrm{H}_{2}$ production for low-temperature fuel cell applications [1, 2]. Cu-based catalysts have traditionally been employed for this 
reaction [3]. In the case of a $\mathrm{Cu}-\mathrm{Zn}-\mathrm{Al}$ oxide catalyst, a linear relationship was obtained between copper surface area and activity, but the linearity is not valid when the preparation method differs, meaning that the WGS is structure-sensitive [4]. Zinc and aluminum oxides are used as the support of catalyst where zinc addition increases the specific rate (activity per $\mathrm{Cu}$ surface area) through decrease of heat of $\mathrm{CO}$ adsorption [5] and increases dispersion of $\mathrm{Cu}$ while aluminum addition only disperses the $\mathrm{Cu}$ phase [6]. Although numerous efforts have been made for increasing activity and stability, the $\mathrm{Cu}$-based catalysts have drawbacks of easy sintering and pyrophoricity [1].

$\mathrm{CeO}_{2}$-supported $\mathrm{Cu}$ catalyst is one of the non-pyrophoric alternatives. While the surface of $\mathrm{Cu} / \mathrm{Al}_{2} \mathrm{O}_{3}$ is saturated with a copper surface phase, fine $\mathrm{CuO}$ crystallites are formed on $\mathrm{Cu} / \mathrm{CeO}_{2} / \mathrm{Al}_{2} \mathrm{O}_{3}$ catalyst due to an interaction between the $\mathrm{CeO}_{2}$ and copper phase [7]. Thus, the reaction pathway should be different. Copper is immiscible to $\mathrm{CeO}_{2}$ lattice and enrichment of copper on the surface was identified by XPS [8]. Proposed active sites includes $\mathrm{Cu}^{1+}$ species that originates from interaction of copper clusters with oxygen species on ceria surface [9], and an isolated copper oxo species formed on $\mathrm{CeO}_{2}$-containig supports [10].

In the effort to improve WGS activity at low temperature, our group has developed a method called oxygen-enhanced water gas shift (OWGS) in which a small amount of oxygen is added to a WGS feed [11]. Since catalyst should stand the oxidative condition, a new formulation, $\mathrm{CeO}_{2}$-supported $\mathrm{Pd}-\mathrm{Cu}$ and Pt-Cu catalysts, were developed. We have found that with these catalysts $\mathrm{CO}$ shift is significantly promoted by $\mathrm{O}_{2}$ addition to the feed without deactivation [12]. Through kinetic analysis, we found that $\mathrm{CO}$ order is low on monometallic noble metal ( $\mathrm{Pd}$ or $\mathrm{Pt}$ ) due to high $\mathrm{CO}$ coverage on the active surface while $\mathrm{CO}$ order is high on $\mathrm{Cu}$ and it is moderate on $\mathrm{Pd}-\mathrm{Cu}$ and $\mathrm{Pt}-\mathrm{Cu}$ bimetallics. $\mathrm{H}_{2} \mathrm{O}$ order showed an opposite trend to the $\mathrm{CO}$ order, which suggested that the reaction proceeds through the association of chemisorbed reactants [13]. By adding oxygen into the feed, only the $\mathrm{CO}$ order increased, which suggested that oxygen removes the chemisorbed $\mathrm{CO}$ to free up the sites for $\mathrm{H}_{2} \mathrm{O}$ chemisorption and to balance these surface 
reactants. The oxygen addition did not promote $\mathrm{CO}$ shift on $\mathrm{Al}_{2} \mathrm{O}_{3}$-supported catalyst and low-surface-area $\mathrm{CeO}_{2}$-supported catalyst $\left(<2 \mathrm{~m}^{2} / \mathrm{g}\right)$ while over $90 \mathrm{~m}^{2} / \mathrm{g}$ of surface area the turnover rate leveled off for $\mathrm{CeO}_{2}$-supported catalysts [14]. However, the structural variation of $\mathrm{Pd}-\mathrm{Cu}$ on different supports and its impacts on catalytic performance were not yet clear. In the present study, X-ray absorption fine structure of $\mathrm{Pd}-\mathrm{Cu}$ bimetallic catalysts was investigated to find the factor to control the catalytic activity. We have also investigated the Pd-Cu structure in an in-situ $\mathrm{CO}$ shift atmosphere.

\section{Experimental}

The $\mathrm{Pd}-\mathrm{Cu}$ bimetallic catalysts were prepared by incipient wetness co-impregnation using a mixed acetone solution of $\mathrm{Pd}$ (II) acetate and $\mathrm{Cu}$ (II) nitrate hemipentahydrate on ceria or alumina supports [14]. Three ceria supports, commercial HSA15 from Rhodia Co. $\left(155 \mathrm{~m}^{2} / \mathrm{g}\right.$ of specific surface area, denoted as $\left.\mathrm{CeO}_{2}(\mathrm{R})\right)$, another commercial $\mathrm{CeO}_{2}$ from Rhodia $\left(>200 \mathrm{~m}^{2} / \mathrm{g}\right.$, denoted as $\mathrm{CeO}_{2}(\mathrm{H})$ ), $\mathrm{CeO}_{2}$ prepared by calcination of cerium (III) nitrate at $600^{\circ} \mathrm{C}$ for 2 hours $\left(74 \mathrm{~m}^{2} / \mathrm{g}\right.$, denoted as $\left.\mathrm{CeO}_{2}(\mathrm{~N})\right)$, and commercial alumina Puralox TH100/150 from Sasol $\left(150 \mathrm{~m}^{2} / \mathrm{g}\right.$, denoted as $\left.\mathrm{Al}_{2} \mathrm{O}_{3}\right)$ were used. All the samples were calcined at $450^{\circ} \mathrm{C}$ for 5 hours after co-impregnation of the precursors. The nominal metal loadings were approximately $2 \mathrm{wt} . \%$ for Pd and $5 \mathrm{wt} . \%$ or $10 \mathrm{wt} . \%$ for $\mathrm{Cu}$. The catalyst composition is designated as $\mathrm{Pd}(2) \mathrm{Cu}(5) / \mathrm{CeO}_{2}(\mathrm{R})$, for instance, where inside the parenthesis following metal species is the metal loading in weight percent. The actual $\mathrm{Cu} / \mathrm{Pd}$ atomic ratio in $\mathrm{Pd}(2) \mathrm{Cu}(5) / \mathrm{CeO}_{2}(\mathrm{R})$ was determined to be 4.18 using Inductively Coupled Plasma Atomic Emission Spectroscopy, which is close to the nominal value. For comparison, monometallic $\mathrm{Cu}$ catalyst was also prepared by impregnating aqueous solution of $\mathrm{Cu}(\mathrm{II})$ nitrate hemipentahydrate on $\mathrm{CeO}_{2}(\mathrm{R})$ support and monometallic $\mathrm{Pd}$ was prepared by impregnating acetone solution of $\mathrm{Pd}(\mathrm{II})$ acetate on $\mathrm{CeO}_{2}(\mathrm{R})$.

$\mathrm{X}$-ray absorption measurements were conducted on the bending magnet beam line (10BM) of the Materials Research Collaborative Access Team (MRCAT) at the Advanced Photon Source, Argonne 
National Laboratory. The detailed method is described elsewhere [11]. The measurements were conducted in-situ with reduction atmosphere in transmission mode using a continuous-flow EXAFS reactor cell (18 in. long, 0.75 in diam.). The catalysts were reduced in $4 \% \mathrm{H}_{2} / \mathrm{He}$ at $260{ }^{\circ} \mathrm{C}$ for $30 \mathrm{~min}$ followed by purging with $\mathrm{He}$ at the same temperature for $30 \mathrm{~min}$ to desorb chemisorbed hydrogen and decompose Pd-H, followed by cooling to room temperature in $\mathrm{He}$ atmosphere. Then the $\mathrm{Pd} K$-edge $(24.350 \mathrm{keV})$ or $\mathrm{Cu}$ $K$-edge $(8.979 \mathrm{keV})$ spectra were obtained. Spectra were also collected at $260^{\circ} \mathrm{C}$ in $\mathrm{He}, 260^{\circ} \mathrm{C}$ in $\mathrm{H}_{2}$, and $260^{\circ} \mathrm{C}$ in a model water gas shift feed $\left(1 \% \mathrm{CO}, 3 \% \mathrm{H}_{2} \mathrm{O}\right.$ balanced by $\left.\mathrm{He}\right)$. Spectra of Pd foil and $\mathrm{Cu}$ foil were acquired simultaneously with those of $\mathrm{Pd}-\mathrm{Cu} / \mathrm{CeO}_{2}$ samples for energy calibration. Experimental phase and amplitude functions were prepared from $\mathrm{Pd}$ and $\mathrm{Cu}$ foil. Theoretical phase and amplitude functions for $\mathrm{Pd}-\mathrm{Cu}$ and $\mathrm{Cu}-\mathrm{Pd}$ were prepared using FEFF 8 and calibrated to $\mathrm{Pd}$ and $\mathrm{Cu}$ foils to determine the appropriate $\mathrm{S}_{0}$, the Debye-Waller factor, and off-set in R.

The methods for catalytic test are described elsewhere [14]. About $0.1 \mathrm{~g}$ of the catalyst (sieved into 0.25 to $0.50 \mathrm{~mm}$ in diameter) was packed in a quartz fixed-bed down-flow reactor with $4 \mathrm{~mm}$ inner diameter $($ aspect ratio $=\sim 1.5)$. The feed gas composition was $9.7 \% \mathrm{CO} / 22.8 \% \mathrm{H}_{2} \mathrm{O} / 6.3 \% \mathrm{CO}_{2} / 37.9 \%$ $\mathrm{H}_{2} / 6.9 \%$ air $\left(1.4 \% \mathrm{O}_{2}\right)$ / argon balance. For measuring WGS activity, the air was simply switched to nitrogen with the same flow rate. The space velocity was around $64,400 \mathrm{~h}^{-1}$ (dry, excluding air and argon). Prior to the catalytic reaction, catalyst was reduced in situ in $7.5 \% \mathrm{H}_{2} / \mathrm{N}_{2}$ flow at $260^{\circ} \mathrm{C}$ for $1 \mathrm{~h}$.

\section{Results and discussion}

\section{1. $\mathrm{Cu} K$-edge spectra}

Fig. 1 shows $\mathrm{Cu} K$-edge XANES spectra of $\mathrm{Pd}-\mathrm{Cu}$ catalysts with various $\mathrm{CeO}_{2}$ and $\mathrm{Al}_{2} \mathrm{O}_{3}$ supports in comparison with that of $\mathrm{Cu}(10) / \mathrm{CeO}_{2}(\mathrm{R})$ catalyst. All the spectra were typical of metallic $\mathrm{Cu}$. The edge energy and very similar shape of the XANES region for $\mathrm{Pd}(2) \mathrm{Cu}(5) / \mathrm{CeO}_{2}(\mathrm{~N}), \mathrm{Pd}(2) \mathrm{Cu}(10) / \mathrm{CeO}_{2}(\mathrm{R})$, and 
$\mathrm{Cu}(10) / \mathrm{CeO}_{2}(\mathrm{R})$ shows that the oxidation state and electronic structure of $\mathrm{Cu}$ is not much influenced by $\mathrm{Pd}$ addition. The slight shifts of the maximums of oscillation at around $9003 \mathrm{eV}$ and $9020 \mathrm{eV}$ towards lower energy by Pd addition could be an indication of a shorter first neighbor distance. The Pd addition to $\mathrm{Cu}$ leads to hybridation changes and charge transfer between $\mathrm{Cu}$ and $\mathrm{Pd}$ resulting in the small net charge transfer from $\mathrm{Cu}$ to $\mathrm{Pd}[15]$. The white line in the XANES of $\mathrm{Pd}-\mathrm{Cu}$ supported on $\mathrm{CeO}_{2}(\mathrm{H})$ and $\mathrm{Al}_{2} \mathrm{O}_{3}$ was slightly larger due to the presence of a small amount of oxidized $\mathrm{Cu}$. A linear combination fit of the spectra to a combination of reference spectra $\left(\mathrm{Cu}^{0}, \mathrm{Cu}^{1+}\right.$ and $\left.\mathrm{Cu}^{2+}\right)$ showed decrease of $\mathrm{Cu}^{0}$ and increase of $\mathrm{Cu}^{1+}$ oxide. Fig. 2 compares the XANES spectra of $\mathrm{Pd}(2) \mathrm{Cu}(10) / \mathrm{CeO}_{2}(\mathrm{R})$ catalyst collected after various treatment conditions: in helium atmosphere at room temperature after reduction, in $\mathrm{H}_{2}$ at $260^{\circ} \mathrm{C}$, and in a WGS stream at $260^{\circ} \mathrm{C}$. The XANES were basically identical suggesting little structural change occurs by heating or changing the atmosphere to the WGS stream after catalyst was reduced.

Fig. 3 shows typical $\mathrm{Cu} K$-edge EXAFS oscillations in $\mathrm{k}$ space for monometallic $\mathrm{Cu}$ and bimetallic Pd-Cu catalysts and Fig. 4 shows the Fourier transform (FT) of various catalysts. For all the samples, the spectrum had a strong scattering at around $2.5 \AA$ (phase corrected) which represents $\mathrm{Cu}$ neighbor. No Pd was apparent from the FT of $\mathrm{Cu} K$-edge spectra likely due to the high $\mathrm{Cu}$ :Pd ratio. Peak intensity reflects the coordination number and therefore particle size. The peak intensity decreased significantly by $\mathrm{Pd}$ addition (Compare the FTs of $\mathrm{Pd}(2) \mathrm{Cu}(10) / \mathrm{CeO}_{2}(\mathrm{R})$ and $\mathrm{Cu}(10) / \mathrm{CeO}_{2}(\mathrm{R})$ ). The low-Cu samples containing $5 \mathrm{wt} \%$ of $\mathrm{Cu}$ showed lower peak intensity than the samples containing 10 wt.\% of $\mathrm{Cu}$ since the crystallites are smaller with low $\mathrm{Cu}$ content, as expected [16]. The Pd-Cu on $\mathrm{CeO}_{2}(\mathrm{H})$ and $\mathrm{Al}_{2} \mathrm{O}_{3}$ showed further lower peak intensity, meaning that their particle sizes are very small. Small-size particles have fraction of oxidized $\mathrm{Cu}$ as evidence in the XANES spectra shown in Fig. 1; however, the $\mathrm{Cu}-\mathrm{O}$ scattering was too small to be fit in the EXAFS, Fig. 4. One of the reasons for the formation of such small particles could be high specific surface area of these supports, over $200 \mathrm{~m}^{2} / \mathrm{g}$ for $\mathrm{CeO}_{2}(\mathrm{H})$ and $150 \mathrm{~m}^{2} / \mathrm{g}$ for $\mathrm{Al}_{2} \mathrm{O}_{3}$. However, support surface area is not a sole factor since $\mathrm{Pd}-\mathrm{Cu}$ on 
$\mathrm{CeO}_{2}(\mathrm{R})$ has larger particles $(\sim 40 \AA$, see Table 1$)$ regardless of the high specific surface area of $\mathrm{CeO}_{2}(\mathrm{R})$ $\left(155 \mathrm{~m}^{2} / \mathrm{g}\right)$. Other conceivable factor is the structure of support surface. In literature, it was reported that the coordination environment of $\mathrm{Cu}^{2+}$ ions depends on the exposed crystal plane of $\mathrm{CeO}_{2}$ surfaces, a five-coordinated $\mathrm{CuO}$ on the (111) and (110) planes and an eight-coordinated $\mathrm{CuO}$ on the (100) plane, which results in the differences in the interactions of the components in the $\mathrm{CuO} / \mathrm{CeO}_{2}$ catalysts [17]. In a liquid-phase $\mathrm{Pt} / \mathrm{CeO}_{2}$ synthesis, the $\mathrm{Pt}$ size was significantly decreased by dehydrating $\mathrm{CeO}_{2}$ through simply calcining the support at $600^{\circ} \mathrm{C}$ [18]. It is also plausible that morphology of the support affects the $\mathrm{Pd}-\mathrm{Cu}$ structure in the impregnation process. The structure of support surface, such as exposed crystal planes, hydrophobicity, and support morphology, could affect the strength of anchoring metal species on support surface in the reduction process.

Table 1 summarizes the fitting results of $\mathrm{Cu} K$-edge spectra of supported $\mathrm{Pd}-\mathrm{Cu}$ with various metal compositions and supports measured in various gas streams. For all catalysts containing both Pd and $\mathrm{Cu}$, there was no indication of Pd neighbors in the fittings of EXAFS spectra even though the Pd $K$-edge analysis implies that $\mathrm{Pd}-\mathrm{Cu}$ bonds exist (in a number of about 2.4 around each $\mathrm{Cu}$ for $\mathrm{Pd}(2) \mathrm{Cu}(5) / \mathrm{Al}_{2} \mathrm{O}_{3}$, given that $\mathrm{Pd}$ is surrounded by $9.8 \mathrm{Cu}$ atoms and that the $\mathrm{Pd} / \mathrm{Cu}$ atomic ratio is 0.24 , see Table 2 ) and there is enough room for identifying them separately in view of the $\mathrm{k}$ range and $\mathrm{R}$ range used. This is likely due to the low $\mathrm{Pd} / \mathrm{Cu}$ fraction in the catalyst and to similar bond distances for $\mathrm{Cu}-\mathrm{Pd}$ and $\mathrm{Cu}-\mathrm{Cu}$ which makes difficult to separate these oscillations. Though $\mathrm{Cu} K$-edge EXAFS analysis did not give any indication of Pd neighbors, it gave rough number of neighbors around $\mathrm{Cu}$. The fit of the $\mathrm{Cu}$ EXAFS shows that $\mathrm{Cu}-\mathrm{Cu}$ bond distance of $\mathrm{Pd}-\mathrm{Cu}$ catalyst is much shorter than that of monometallic $\mathrm{Cu}$ catalyst suggesting an electronic perturbation in these catalysts. The $\mathrm{Pd}-\mathrm{Cu}$ bond distance is also short, close to or even shorter than $\mathrm{Cu}-\mathrm{Cu}$ bond distance of pure copper, which will be shown later in the results of $\mathrm{Pd} K$-edge spectra.

In an atomic-scale STM imaging combined with topography of tunneling conductance $(d I / d V)$ for $\mathrm{Pd}-\mathrm{Cu}$ alloy on $\mathrm{Cu}(111)$ surface, it was found that $\mathrm{Pd}$ atoms can substitute into $\mathrm{Cu}$ surface with little 
geometric changes [19]. The $d I / d V$ topography showed $\mathrm{Pd}$ atoms dispersed in a $\mathrm{Cu}$ lattice are almost electronically identical to their host $\mathrm{Cu}$ atoms. In addition, $\mathrm{Pt}-\mathrm{Cu}$ bonds are stronger than $\mathrm{Pd}-\mathrm{Pd}$ or $\mathrm{Cu}-\mathrm{Cu}$ bonds which drives $\mathrm{Pd}$ to be dispersed in $\mathrm{Cu}$ lattice. If $\mathrm{Pd}$ is readily dissolved and randomly distributed in the $\mathrm{Cu}$ NP's, the $\mathrm{Cu}$ EXAFS would be expected to be dominated by the high fraction of $\mathrm{Cu}-\mathrm{Cu}$ scattering.

Fig. 5 shows a relationship between $\mathrm{Cu}-\mathrm{Cu}$ bond distance and $\mathrm{Cu}-\mathrm{Cu}$ coordination number. The latter reflects particle size. The $\mathrm{Cu}-\mathrm{Cu}$ bond distance decreased as the $\mathrm{Cu}-\mathrm{Cu}$ coordination number decreased. When the coordination number was 11 for the monometallic $\mathrm{Cu}(10) / \mathrm{CeO}_{2}$ case, which corresponds to $75 \AA$ of particle size, the bond distance was $2.55 \AA$, which is typical of the $\mathrm{Cu}-\mathrm{Cu}$ distance of bulk copper. By adding $\mathrm{Pd}$ to $\mathrm{Cu}$, the bond distance became even shorter than that of bulk copper. For the $\mathrm{Pd}(2) \mathrm{Cu}(5) / \mathrm{CeO}_{2}(\mathrm{~N})$ sample, the coordination number was 7.3 , which corresponds to $24 \AA$ of particle size, the bond distance was $2.50 \AA$, which is clearly shorter than that of bulk copper. The lattice shrinkage becomes more remarkable when the size was smaller $\left(\mathrm{R}_{\mathrm{Cu}-\mathrm{Cu}}=2.46 \AA\right.$ for the $\mathrm{Pd}(2) \mathrm{Cu}(5) / \mathrm{CeO}_{2}(\mathrm{H})$ sample), indicating that there is a strong electronic perturbation on $\mathrm{Cu}$ through interactions with $\mathrm{Pd}$.

In EXAFS studies of supported $\mathrm{Pd}-\mathrm{Cu}$, bond lengths are not so shortened as that observed in the present study. Molenbroek et al. reported that $\mathrm{Cu}-\mathrm{Cu}$ bond length is little influenced by a particle-size reduction of $\mathrm{Pd}-\mathrm{Cu}$ on $\mathrm{Al}_{2} \mathrm{O}_{3}$ support although they also commented that the anharmonic vibrations cause underestimation of the coordination number for small particles [20]. Batista et al. investigated effect of metal loadings and reported no big impact on the bond distance in $\mathrm{Pd}-\mathrm{Cu} / \mathrm{Al}_{2} \mathrm{O}_{3}$ [21]. The $\mathrm{Pd}-\mathrm{Cu}$ distance was roughly the arithmetic mean of distances of two monometallic systems. Fernandez-Garcia et al. showed that bond distance around a $\mathrm{Cu}$ center increases by c.a. $10 \%$ by alloying and that around a $\mathrm{Pd}$ center decreases by c.a. $2 \%$ by alloying [22]. Li et al. detected a slight lattice compression of $\mathrm{Cu}$ in their $\mathrm{Cu} @ \mathrm{Pd}$ core-shell nanowire by the XRD pattern [23]. They suggested a strain of the embracement of Pd layer as the reason, but no further detail was pursued. Compared to these reports, our Pd-Cu system 
exhibited a marked shrinkage of $\mathrm{Cu}$ owing to the very small particle size $(<\mathrm{ca} .4 \mathrm{~nm})$, which was realized by the preparation condition using palladium acetate as a metal source.

\subsection{Pd $K$-edge spectra}

Fig. 6 shows Pd $K$-edge XANES spectra of monometallic Pd and bimetallic Pd-Cu on various supports. The spectra of monometallic Pd were typical of bulk Pd while those of Pd-Cu samples were clearly different indicating formation of an alloy. The decrease in white line intensity indicates an increase of charge on the unoccupied orbitals of Pd. Many XPS studies show that there is electronic rearrangement induced by intermetallic bond, i.e. binding energy of $\mathrm{Pd}$ shifts to higher energy by $\mathrm{Cu}$ addition and that of $\mathrm{Cu}$ shifts to lower energy by Pd addition [24-27]. Some reports concluded that the charge moves from Pd to $\mathrm{Cu}$ based on XPS measurements while the others accounted the experimental results for hybridation and polarization of orbitals. Since the work function of $\mathrm{Pd}$ is ca. $0.5 \mathrm{eV}$ higher than that of $\mathrm{Cu}$, the latter is more probable. According to the theoretical study by Fernandez-Garcia et al., the charge in the Pd 4d and $\mathrm{Cu} 4 \mathrm{sp}$ subbands are decreased by polarization and charge transfer, respectively, and charge in the Pd $5 \mathrm{sp}$ subbands is increased by the $\mathrm{Pd}-\mathrm{Cu}$ bond formation [15].

The spectra of monometallic $\mathrm{Pd}$ supported on $\mathrm{CeO}_{2}$ or SBA-15 was very close to the $\mathrm{Pd}$ foil except that the amplitude of the XANES region for these samples was smaller than that of Pd foil (not shown in the figure). The smaller amplitude of the oscillation for $\mathrm{Pd}(2) / \mathrm{CeO}_{2}(\mathrm{R})$ compared to $\operatorname{Pd}(4) / S B A-15$ would be due to the lower coordination number, which probably comes from low $\mathrm{Cu}$ loading and thus smaller particle size in the former. Among Pd-Cu samples, the XANES spectra were all similar regardless of $\mathrm{Cu}$ content. Highly dispersed $\mathrm{Pd}$ in $\mathrm{Cu}$ would make a similar environment. Also, the XANES spectra taken in helium at room temperature after $\mathrm{H}_{2}$ reduction, in $\mathrm{H}_{2}$ at $260^{\circ} \mathrm{C}$, and in WGS stream at $260^{\circ} \mathrm{C}$ and $350^{\circ} \mathrm{C}$ were identical though the spectra were not presented in the figure. Again, there was no effect of the atmosphere and temperature conditions on the local structure of Pd-Cu. 
In Fig. 7, typical Pd $K$-edge EXAFS oscillations in k space for monometallic Pd and bimetallic Pd-Cu catalysts were presented and Fourier transforms of various catalysts were shown in Fig. 8. Two peaks at $2.5 \AA$ and $2 \AA$ (phase not corrected) in Fig. 8 are typical of monometallic Pd crystal. Smaller peaks for $\mathrm{Pd}(2) / \mathrm{CeO}_{2}(\mathrm{R})$ than $\mathrm{Pd}(4) / \mathrm{SBA} 15$ is ascribed to lower $\mathrm{Pd}$ content and thus smaller particle size. The small peaks at $\mathrm{R}=3.7,4.6$, and 5.1 $\AA$ seen in the FT of EXAFS spectra of Pd(4)/SBA-15 are coherent with the larger Pd particle size obtained for this catalyst since they coincide with the peaks in bulk Pd [28]. The Pd-Cu samples had a single peak at shorter distance indicating that the neighbor of Pd is mainly $\mathrm{Cu}$. The fitting parameters were given in Table 2. In all the $\mathrm{Pd}-\mathrm{Cu}$ catalysts, only $\mathrm{Cu}$ neighbors were visible, i.e. metallic $\mathrm{Pd}$ is surrounded by $\mathrm{Cu}$ atoms. The $\mathrm{Pd}-\mathrm{Pd}$ bond distance in monometallic $\mathrm{Pd}$ was 2.72 $\AA$, which is slightly shorter than that of Pd foil, $2.75 \AA$. The Pd-Cu bond distance in Pd-Cu catalysts was $2.55 \AA$, which is about $0.10 \AA$ shorter than the sum of the atomic radii, $(2.75+2.55) / 2$, or $2.65 \AA$, and close to that of $\mathrm{Cu}$ foil. The geometry of Pd neighbor seems very similar to the monometallic $\mathrm{Cu}$ [19].

The $\mathrm{Al}_{2} \mathrm{O}_{3}$-supported catalyst showed much lower coordination number for $\mathrm{Pd}-\mathrm{Cu}$ obtained from $\mathrm{Pd} K$-edge spectra than that for $\mathrm{Cu}$-Cu obtained from $\mathrm{Cu} K$-edge spectra while $\mathrm{CeO}_{2}$-supported samples showed similar values. This means that the elemental distribution in the nanoparticles differs on $\mathrm{Al}_{2} \mathrm{O}_{3}$ and $\mathrm{CeO}_{2}$ supports. On the former, $\mathrm{Pd}$ is primarily at the interior of the nanoparticles and with a $\mathrm{Cu}$-rich surface, i.e., a Pd core-Cu shell morphology, while on the latter $\mathrm{Pd}$ and $\mathrm{Cu}$ are randomly distributed. It is known that $\mathrm{Cu}$ interacts with $\mathrm{Al}_{2} \mathrm{O}_{3}$ strongly to bring an enrichment of $\mathrm{Cu}$ on the surface of $\mathrm{Pd}-\mathrm{Cu}$ particles when they are supported on $\mathrm{Al}_{2} \mathrm{O}_{3}$ support $[21,29]$. The surface enrichment is due partly to the lower surface free energy of $\mathrm{Cu}$ than $\mathrm{Pd}[30,31]$. This also occurs on $\mathrm{SiO}_{2}$ [20, 31] and MCM-41[26], but lesser extent. For $\mathrm{Pd}-\mathrm{Cu} / \mathrm{C}$ prepared by a polyol method with citric acid stabilizer, $\mathrm{Pd}$ was more on the surface [32]. In this case, the presence of a strong adsorbate (citric acid in this case) would bring Pd to the surface [19]. Consistent with literature, $\mathrm{Cu}$ seems to interact strongly with $\mathrm{Al}_{2} \mathrm{O}_{3}$ in the present study while both $\mathrm{Pd}$ and $\mathrm{Cu}$ seem to interact with $\mathrm{CeO}_{2}$. This is also inspired by our previous study of 
temperature-programmed reduction where $\mathrm{Pd}-\mathrm{Cu}$ oxides were partly reduced in hydrogen below the room temperature on $\mathrm{Al}_{2} \mathrm{O}_{3}$ while $\mathrm{Pd}-\mathrm{Cu}$ oxides were reduced simultaneously above room temperature on $\mathrm{CeO}_{2}$ support [14]. The higher was the surface area of $\mathrm{CeO}_{2}$, the less reducible was the metal species. The weaker interaction of $\mathrm{Pd}$ and $\mathrm{Al}_{2} \mathrm{O}_{3}$ could lead $\mathrm{Pd}$ to nucleate the metallic nanoparticles during the calcination in the air or in an early stage of the hydrogen reduction. On the other hand, the strong interaction of both $\mathrm{Pd}$ and $\mathrm{Cu}$ with $\mathrm{CeO}_{2}$ would lead to homogeneous distribution of the two components in the particles.

\section{$\underline{\text { 3.3 Catalytic activities and Pd-Cu structure }}$}

The activity data for WGS and OWGS were presented in Fig. 9. The "WGS in OWGS" is the percentage equivalent to the net $\mathrm{H}_{2}$ production and "CO oxidation in OWGS" is the difference of total $\mathrm{CO}$ conversion and "WGS in OWGS". $\mathrm{O}_{2}$ addition increased $\mathrm{CO}$ conversion significantly and net $\mathrm{H}_{2}$ production to certain extent. Considering that Pd-containing catalysts show severe $\mathrm{H}_{2}$ combustion (low selectivity for $\mathrm{CO}$ oxidation) with $\mathrm{O}_{2}$ addition [33], promotion of $\mathrm{CO}$ shift would be significant on $\mathrm{CeO}_{2}$-suported catalysts. On $\mathrm{Al}_{2} \mathrm{O}_{3}$-supported Pd-Cu, there was no WGS ( $\mathrm{H}_{2}$ production) in OWGS while

there was a measurable WGS rate in the absence of $\mathrm{O}_{2}$, which would be attributed to both lack of selectivity for $\mathrm{CO}$ oxidation and poor activity for $\mathrm{CO}$ shift. This difference is likely caused by the differences in Pd-Cu surface structure and metal-support interaction. Since Pd is distributed more in the interior of nanoparticles on $\mathrm{Al}_{2} \mathrm{O}_{3}$ support, the surface would have $\mathrm{Cu}$ character which less chemisorbs $\mathrm{CO}$. In terms of the metal-support interaction, the activation of $\mathrm{H}_{2} \mathrm{O}$ would be weak on $\mathrm{Pd}-\mathrm{Cu}$ with $\mathrm{Al}_{2} \mathrm{O}_{3}$ support. Our previous kinetic study, in which the reaction order in $\mathrm{CO}$ drastically increased by $\mathrm{O}_{2}$ addition to a WGS feed on $\mathrm{CeO}_{2}$-supported $\mathrm{Pd}-\mathrm{Cu}$, but not on $\mathrm{Al}_{2} \mathrm{O}_{3}$-supported $\mathrm{Pd}-\mathrm{Cu}$, led to the conclusion that $\mathrm{O}_{2}$ addition removes a part of $\mathrm{CO}$ to free up the sites for $\mathrm{H}_{2} \mathrm{O}$ chemisorption and effectively to activate $\mathrm{H}_{2} \mathrm{O}$ on $\mathrm{CeO}_{2}$-supported $\mathrm{Pd}-\mathrm{Cu}[14]$. 
Although there is no data taken in a gas containing $\mathrm{O}_{2}$ and thus XAS spectra in OWGS conditions could be different from those in WGS conditions, we think the structural change in the presence of $\mathrm{O}_{2}$ is minor for two reasons. First, the local structure (XANES spectra) of copper in $\mathrm{Pt}-\mathrm{Cu} / \mathrm{CeO}{ }_{2}$ was almost identical for $\mathrm{H}_{2}$ stream and PROX stream $\left(10 \% \mathrm{CO}, 5 \% \mathrm{O}_{2}, 10 \% \mathrm{H}_{2}\right.$, and $\mathrm{N}_{2}$ balance $)$ at $100^{\circ} \mathrm{C}$ according to literature [34]. Second, Haruta et al. observed only surface morphology change in Au nanoparticle supported on $\mathrm{CeO}_{2}$ in various $\mathrm{CO} /$ air mixed atmospheres using in-situ TEM technique. When $\mathrm{CO} /$ air ratio was small, the edge site of Au particle became round, suggesting some surface rearrangement of atoms occurred [35]. Though $\mathrm{Pd}-\mathrm{Cu}$ is more vulnerable to an oxidizing atmosphere than the $\mathrm{Au} / \mathrm{CeO}_{2}$ system, our OWGS condition is quite reducing $\left(\mathrm{O}_{2}\right.$ is present in excess $\left.\mathrm{H}_{2}\right)$, thus the bulk structure of Pd-Cu would not change much by the addition of small amount of $\mathrm{O}_{2}$ and change of nanoparticle structure would be rather superficial.

Among the $\mathrm{CeO}_{2}$-supported $\mathrm{Pd}-\mathrm{Cu}$, the catalysts with high-surface-area $\mathrm{CeO}_{2}$ support tends to give high catalytic activity, but it is not strictly true, e.g. $\mathrm{Pd}-\mathrm{Cu} / \mathrm{CeO}_{2}(\mathrm{R})$ is more active than $\mathrm{Pd}-\mathrm{Cu} / \mathrm{CeO}_{2}(\mathrm{H})$, meaning that $\mathrm{CeO}_{2}$ surface area is not a sole factor controlling the reaction. Also, activity was irrelevant to the alloy particle size estimated from the $\mathrm{Cu} K$-edge EXAFS, meaning that the peripheral length of alloy particles (metal- $\mathrm{CeO}_{2}$ interfacial length) is not a direct factor either. The structure of metal- $\mathrm{CeO}_{2}$ interface or the balance of electronic interactions among $\mathrm{Pd}, \mathrm{Cu}$, and $\mathrm{CeO}_{2}$ could be of importance. The electronic interaction between two metal components on $\mathrm{CeO}_{2}$ was different from those on other supports as evidenced by the less reducible property in our previous TPR study.

It should be noted that $\mathrm{Pd}(2)-\mathrm{Cu}(5) / \mathrm{CeO}_{2}(\mathrm{R})$ outperformed $\mathrm{Pd}(2)-\mathrm{Cu}(5) / \mathrm{CeO}_{2}(\mathrm{H})$ in the OWGS stream containing $\mathrm{H}_{2}$ and $\mathrm{CO}_{2}$ while these catalysts performed almost identically in an OWGS stream without $\mathrm{H}_{2}$ and $\mathrm{CO}_{2}$ [14]. One negative factor for high surface area $\mathrm{CeO}_{2}$ would be a slow $\mathrm{CO}_{2}$ desorption and easy accumulation of carbonate on the surface. Another negative factor could be the small $\mathrm{Pd}-\mathrm{Cu}$ nanoparticle size. In methanol electrooxidation reaction, the size reduction of Pt catalyst below $5 \mathrm{~nm}$ 
drastically increases the number of unsaturated Pt atoms on the surface, which causes strong retention of intermediate $\mathrm{CO}[36,37]$ and oxygenated species like $\mathrm{OH}[38,39]$. Similar negative effect is possible for the present $\mathrm{Pd}-\mathrm{Cu}$ system. The metal-support interaction and/or interfacial structure could affect these chemisorption properties of intermediates and products. Further investigation is necessary for elucidating the quantitative contributions of the two factors.

\section{Conclusions}

Using the X-ray absorption technique, the local structures of $\mathrm{Pd}$ and $\mathrm{Cu}$ in $\mathrm{Pd}-\mathrm{Cu}$ catalysts were investigated in comparison with monometallic catalysts. From $\mathrm{Cu} K$-edge spectra, only $\mathrm{Cu}$ neighbors were recognized and $\mathrm{Pd}$ neighbor was invisible. The particle size estimated from the $\mathrm{Cu}-\mathrm{Cu}$ coordination number was much smaller for $\mathrm{Pd}-\mathrm{Cu}$ system than monometallic $\mathrm{Cu}$. The $\mathrm{Cu}-\mathrm{Cu}$ bond distance in the $\mathrm{Pd}-\mathrm{Cu}$ system was much shorter than that of monometallic $\mathrm{Cu}$, which was correlated to the small particle size. The Pd $K$-edge XANES looks like an alloy, but in the EXAFS spectra, only $\mathrm{Cu}$ neighbors were identified. Thus, $\mathrm{Pd}$ is atomically dispersed in the $\mathrm{Cu}$ lattice. The Fourier transform of $\mathrm{Pd} K$-edge spectra showed that $\mathrm{Pd}$ is geometrically identical to $\mathrm{Cu}$, i.e. the $\mathrm{Pd}-\mathrm{Cu}$ bond distance is much shorter than that of

monometallic Pd $(2.75 \AA)$ and is close to $\mathrm{Cu}-\mathrm{Cu}$ bond distance of monometallic $\mathrm{Cu}(2.55 \AA)$. Although such structural feature (small particle size and lattice shrinkage) of $\mathrm{Pd}-\mathrm{Cu}$ is not a sole factor for the enhanced $\mathrm{CO}$ shift activity, the interactions among these two metal components and $\mathrm{CeO}_{2}$ support was suggested to control the $\mathrm{CO}$ shift activity.

\section{Acknowledgment}

We wish to thank the U.S. Department of Energy, National Energy Technology Laboratory and US Office of Naval Research for partial support of this work on liquid fuel processing for fuel cells. Use 
of the Advanced Photon Source is supported by the U.S. Department of Energy, Office of Science, and Office of Basic Energy Sciences, under Contract DE-AC02-06CH11357. MRCAT operations are supported by the U.S. Department of Energy and the MRCAT member institutions. We also thank Rhodia Co. for generously supplying $\mathrm{CeO}_{2}$ support. 
Tables

Table 1 Fitting parameters of $\mathrm{Cu} K$-edge EXAFS spectra

\begin{tabular}{|l|l|l|l|l|l|l|l|}
\hline Sample & Condition & Scatter & $\mathrm{N}$ & $\begin{array}{l}\mathrm{R} \\
(\AA)\end{array}$ & $\begin{array}{l}\text { DWF } \\
\left(\mathrm{x} 10^{3}\right)\end{array}$ & $\begin{array}{l}\mathrm{E}_{\mathrm{o}} \\
(\mathrm{eV})\end{array}$ & $\begin{array}{l}\text { Particle } \\
\text { size }(\AA)\end{array}$ \\
\hline $\mathrm{Cu}(10) / \mathrm{CeO}_{2}(\mathrm{R})$ & $\mathrm{He}$ R.T. & $\mathrm{Cu}-\mathrm{Cu}$ & 11.0 & 2.55 & 1.0 & 0.9 & 75 \\
\hline $\mathrm{Pd}(2) \mathrm{Cu}(5) / \mathrm{Al}_{2} \mathrm{O}_{3}$ & $\mathrm{He}$ R.T. & $\mathrm{Cu}-\mathrm{Cu}$ & 5.5 & 2.48 & 4.0 & -7.6 & 14 \\
\hline & $\mathrm{H}_{2} 260^{\circ} \mathrm{C}$ & $\mathrm{Cu}-\mathrm{Cu}$ & 5.5 & 2.46 & 8.0 & -8.9 & \\
\hline & WGS $260^{\circ} \mathrm{C}$ & $\mathrm{Cu}-\mathrm{Cu}$ & 5.5 & 2.47 & 8.0 & -8.8 & \\
\hline $\mathrm{Pd}(2) \mathrm{Cu}(5) / \mathrm{CeO}_{2}(\mathrm{~N})$ & $\mathrm{He} \mathrm{R} . \mathrm{T}$. & $\mathrm{Cu}-\mathrm{Cu}$ & 7.3 & 2.50 & 3.0 & -4.3 & 24 \\
\hline & $\mathrm{H}_{2} 260^{\circ} \mathrm{C}$ & $\mathrm{Cu}-\mathrm{Cu}$ & 7.7 & 2.49 & 8.0 & -5.5 & \\
\hline & WGS $260^{\circ} \mathrm{C}$ & $\mathrm{Cu}-\mathrm{Cu}$ & 7.6 & 2.48 & 8.0 & -6.7 & \\
\hline $\mathrm{Pd}(2) \mathrm{Cu}(5) / \mathrm{CeO}_{2}(\mathrm{H})$ & $\mathrm{He}$ R.T. & $\mathrm{Cu}-\mathrm{Cu}$ & 4.9 & 2.46 & 5.0 & -8.2 & 12 \\
\hline $\mathrm{Pd}(2) \mathrm{Cu}(10) / \mathrm{CeO}_{2}(\mathrm{R})$ & He R.T. & $\mathrm{Cu}-\mathrm{Cu}$ & 9.0 & 2.53 & 2.0 & -1.5 & 41 \\
\hline
\end{tabular}

Fitting was conducted with k range of $2.8-10.8 \AA^{-1}$ and $\mathrm{R}$ range of $1-3 \AA$. 
Table 2 Fitting parameters of Pd $K$-edge EXAFS spectra

\begin{tabular}{|c|c|c|c|c|c|c|c|}
\hline Sample & Condition & Scatter & $\mathrm{N}$ & $\begin{array}{l}\mathrm{R} \\
(\AA)\end{array}$ & $\begin{array}{l}\text { DWF } \\
\left(\times 10^{3}\right)\end{array}$ & $\begin{array}{l}E_{o} \\
(e V)\end{array}$ & $\begin{array}{l}\text { Particle } \\
\text { size }(\AA)\end{array}$ \\
\hline $\mathrm{Pd}(4) / \mathrm{SBA}-15$ & $\mathrm{H}_{2} 400^{\circ} \mathrm{C}$ & $\mathrm{Pd}-\mathrm{Pd}$ & 8.1 & 2.73 & 1.0 & -0.2 & 30 \\
\hline \multirow[t]{3}{*}{$\mathrm{Pd}(2) / \mathrm{CeO}_{2}$} & He RT & $\mathrm{Pd}-\mathrm{Pd}$ & 5.5 & 2.71 & 4.0 & -1.3 & 13 \\
\hline & WGS $260^{\circ} \mathrm{C}$ & Pd-Pd & 5.8 & 2.72 & 5.0 & -0.5 & \\
\hline & WGS $350^{\circ} \mathrm{C}$ & $\mathrm{Pd}-\mathrm{Pd}$ & 6.0 & 2.71 & 6.0 & -0.4 & \\
\hline \multirow[t]{4}{*}{$\mathrm{Pd}(2) \mathrm{Cu}(5) / \mathrm{Al}_{2} \mathrm{O}_{3}$} & He RT & $\mathrm{Pd}-\mathrm{Cu}$ & 9.8 & 2.56 & 2.0 & -0.1 & \\
\hline & $\mathrm{H}_{2} 260^{\circ} \mathrm{C}$ & $\mathrm{Pd}-\mathrm{Cu}$ & 9.6 & 2.54 & 6.5 & -1.6 & \\
\hline & WGS $260^{\circ} \mathrm{C}$ & $\mathrm{Pd}-\mathrm{Cu}$ & 9.8 & 2.54 & 6.5 & -1.7 & \\
\hline & WGS $350^{\circ} \mathrm{C}$ & $\mathrm{Pd}-\mathrm{Cu}$ & 9.8 & 2.53 & 8.0 & -1.8 & \\
\hline $\mathrm{Pd}(2) \mathrm{Cu}(5) / \mathrm{CeO}_{2}(\mathrm{H})$ & He RT & $\mathrm{Pd}-\mathrm{Cu}$ & 5.4 & 2.53 & 4.0 & -1.9 & \\
\hline $\mathrm{Pd}(2) \mathrm{Cu}(5) / \mathrm{CeO}_{2}(\mathrm{~N})$ & He RT & $\mathrm{Pd}-\mathrm{Cu}$ & 7.8 & 2.56 & 3.0 & 1.4 & \\
\hline \multirow[t]{4}{*}{$\mathrm{Pd}(2) \mathrm{Cu}(5) / \mathrm{CeO}_{2}(\mathrm{R})$} & He RT & $\mathrm{Pd}-\mathrm{Cu}$ & 8.4 & 2.55 & 3.0 & 0.2 & \\
\hline & $\mathrm{H}_{2} 260^{\circ} \mathrm{C}$ & $\mathrm{Pd}-\mathrm{Cu}$ & 8.4 & 2.53 & 7.0 & -1.6 & \\
\hline & WGS $260^{\circ} \mathrm{C}$ & $\mathrm{Pd}-\mathrm{Cu}$ & 8.5 & 2.55 & 7.0 & -1.0 & \\
\hline & WGS $350^{\circ} \mathrm{C}$ & $\mathrm{Pd}-\mathrm{Cu}$ & 8.5 & 2.54 & 7.5 & -0.5 & \\
\hline \multirow[t]{4}{*}{$\mathrm{Pd}(2) \mathrm{Cu}(10) / \mathrm{CeO}_{2}(\mathrm{R})$} & He RT & $\mathrm{Pd}-\mathrm{Cu}$ & 9.8 & 2.56 & 3.0 & 1.3 & \\
\hline & $\mathrm{H}_{2} 260^{\circ} \mathrm{C}$ & $\mathrm{Pd}-\mathrm{Cu}$ & 9.6 & 2.54 & 7.0 & -0.6 & \\
\hline & WGS $260^{\circ} \mathrm{C}$ & $\mathrm{Pd}-\mathrm{Cu}$ & 10.3 & 2.54 & 7.0 & -1.0 & \\
\hline & WGS $350^{\circ} \mathrm{C}$ & $\mathrm{Pd}-\mathrm{Cu}$ & 10.3 & 2.54 & 7.5 & -0.1 & \\
\hline
\end{tabular}

Fitting was conducted with k range of $2.6-12.3 \AA^{-1}$ and $\mathrm{R}$ range of $1-3 \AA$. 


\section{Figure captions}

Fig. $1 \mathrm{Cu} K$-edge XANES of the catalysts measured at room temperature in helium after hydrogen reduction at $260^{\circ} \mathrm{C}$

From the top, $\mathrm{Pd}(2) \mathrm{Cu}(5) / \mathrm{Al}_{2} \mathrm{O}_{3} ; \mathrm{Pd}(2) \mathrm{Cu}(5) / \mathrm{CeO}_{2}(\mathrm{H}) ; \mathrm{Pd}(2) \mathrm{Cu}(5) / \mathrm{CeO}_{2}(\mathrm{~N}) ; \mathrm{Pd}(2) \mathrm{Cu}(10) / \mathrm{CeO}_{2}(\mathrm{R})$; $\mathrm{Cu}(10) / \mathrm{CeO}_{2}(\mathrm{R})$.

Fig. $2 \mathrm{Cu} K$-edge XANES of $\mathrm{Pd}(2) \mathrm{Cu}(10) / \mathrm{CeO}_{2}(\mathrm{R})$ catalysts measured in various conditions From the top, at room temperature in helium after hydrogen reduction at $260^{\circ} \mathrm{C}$; in hydrogen at $260^{\circ} \mathrm{C}$; in a WGS stream at $260^{\circ} \mathrm{C}$.

Fig. $3 \mathrm{Cu}$ K-edge EXAFS oscillations in $\mathrm{k}$ space $\left(\mathrm{k}^{2}\right.$-weighting) of $\mathrm{Cu}(10) / \mathrm{CeO}_{2}(\mathrm{R})$ and $\mathrm{Pd}(2) \mathrm{Cu}(10) / \mathrm{CeO}_{2}(\mathrm{R})$ catalysts

Blue: $\mathrm{Cu}(10) / \mathrm{CeO}_{2}(\mathrm{R})$; Red: $\mathrm{Pd}(2) \mathrm{Cu}(10) / \mathrm{CeO}_{2}(\mathrm{R})$ measured at room temperature in helium after hydrogen reduction at $260^{\circ} \mathrm{C}$.

Fig. 4 Fourier transform of $\mathrm{Cu} K$-edge EXAFS of the catalysts measured at room temperature in helium after hydrogen reduction at $260^{\circ} \mathrm{C}$

$k^{2}: \Delta \mathrm{k}=2.8-10.8 ;$ Pink: $\mathrm{Pd}(2) \mathrm{Cu}(5) / \mathrm{Al}_{2} \mathrm{O}_{3}$; dashed red: $\mathrm{Pd}(2) \mathrm{Cu}(5) / \mathrm{CeO}_{2}(\mathrm{H})$; dashed purple: $\mathrm{Pd}(2) \mathrm{Cu}(5) / \mathrm{CeO}_{2}(\mathrm{~N})$; dashed blue: $\mathrm{Pd}(2) \mathrm{Cu}(10) / \mathrm{CeO}_{2}(\mathrm{R})$; black: $\mathrm{Cu}(10) / \mathrm{CeO}_{2}(\mathrm{R})$.

Fig. 5 Correlation between $\mathrm{Cu}-\mathrm{Cu}$ coordination number and $\mathrm{Cu}-\mathrm{Cu}$ bond distance in $\mathrm{Pd}-\mathrm{Cu}$ catalysts The error range of bond length was about $0.02 \AA$ in the fitting. 
Fig. 6 Pd $K$-edge XANES of the catalysts measured at room temperature in helium after hydrogen reduction at $260^{\circ} \mathrm{C}$

From the top, $\mathrm{Pd}(4) / \mathrm{SBA}-15 ; \quad \mathrm{Pd}(2) / \mathrm{CeO}_{2}(\mathrm{R}) ; \quad \mathrm{Pd}(2) \mathrm{Cu}(10) / \mathrm{CeO}_{2}(\mathrm{R}) ; \quad \mathrm{Pd}(2) \mathrm{Cu}(5) / \mathrm{CeO}_{2}(\mathrm{R})$; $\mathrm{Pd}(2) \mathrm{Cu}(5) / \mathrm{Al}_{2} \mathrm{O}_{3}$.

Fig. 7 Pd K-edge EXAFS oscillations in $\mathrm{k}$ space $\left(\mathrm{k}^{2}\right.$-weighting) of $\mathrm{Pd}(4) / \mathrm{SBA}-15$ and $\mathrm{Pd}(2) \mathrm{Cu}(5) / \mathrm{Al}_{2} \mathrm{O}_{3}$ catalysts

Blue: $\mathrm{Pd}(4) / \mathrm{SBA}-15$ measured at room temperature in helium after hydrogen reduction at $400^{\circ} \mathrm{C}$; Red: $\mathrm{Pd}(2) \mathrm{Cu}(5) / \mathrm{Al}_{2} \mathrm{O}_{3}$ measured at room temperature in helium after hydrogen reduction at $260^{\circ} \mathrm{C}$.

Fig. 8 Fourier transform of Pd $K$-edge EXAFS of the catalysts treated in hydrogen at $260^{\circ} \mathrm{C}$ and cooled to room temperature in helium

$\mathrm{k}^{2}: \quad \Delta \mathrm{k}=2.6-12.3 ;$ Pink: $\mathrm{Pd}(4) / \mathrm{SBA}-15 ;$ dashed red: $\mathrm{Pd}(2) / \mathrm{CeO}_{2}(\mathrm{R}) ;$ dashed purple: $\mathrm{Pd}(2) \mathrm{Cu}(10) / \mathrm{CeO}_{2}(\mathrm{R})$; dashed blue: $\mathrm{Pd}(2) \mathrm{Cu}(5) / \mathrm{CeO}_{2}(\mathrm{R})$; black: $\mathrm{Pd}(2) \mathrm{Cu}(5) / \mathrm{Al}_{2} \mathrm{O}_{3}$.

Fig. 9 WGS and OWGS activities of Pd-Cu catalysts on various supports

Feed: $9.7 \% \mathrm{CO} / 22.8 \% \mathrm{H}_{2} \mathrm{O} / 6.3 \% \mathrm{CO}_{2} / 37.9 \% \mathrm{H}_{2} / 6.9 \% \mathrm{~N}_{2}$ (for WGS) or air (for OWGS) balanced by argon. Temperature: $260^{\circ} \mathrm{C}$. GHSV: $64,400 \mathrm{~h}^{-1}$ (dry). 


\section{Reference}

[1] A.F. Ghenciu, Curr. Opin. Solid State Mater. Sci., 6 (2002) 389-399.

[2] C.S. Song, Catal. Today, 77 (2002) 17-49.

[3] D.C. Grenoble, M.M. Estadt, D.F. Ollis, J. Catal., 67 (1981) 90-102.

[4] R.A. Hadden, P.J. Lambert, C. Ranson, Appl. Catal. A: Gen., 122 (1995) L1-L4.

[5] R.N. d'Alnoncourt, M. Kurtz, H. Wilmer, E. Loffler, V. Hagen, J.Y. Shen, M. Muhler, J. Catal., 220 (2003) 249-253.

[6] M. Saito, K. Murata, Catal. Surveys Asia, 8 (2004) 285-294.

[7] P.K. Cheekatamarla, C.M. Finnerty, J. Power Sources, 160 (2006) 490-499.

[8] W. Liu, M. Flytzani-Stephanopoulos, J. Catal., 153 (1995) 317-332.

[9] X.Q. Wang, J.A. Rodriguez, J.C. Hanson, D. Gamarra, A. Martinez-Arias, M. Fernandez-Garcia, J. Phys. Chem. B, 110 (2006) 428-434.

[10] P. Ratnasamy, D. Srinivas, C.V.V. Satyanarayana, P. Manikandan, R.S.S. Kumaran, M. Sachin, V.N. Shetti, J. Catal., 221 (2004) 455-465.

[11] E.B. Fox, S. Velu, M.H. Engelhard, Y.H. Chin, J.T. Miller, J. Kropf, C.S. Song, J. Catal., 260 (2008) 358-370.

[12] J. Kugai, J.T. Miller, N. Guo, C. Song, J. Catal., 277 (2011) 46-53.

[13] J. Kugai, E.B. Fox, C. Song, Appl. Catal. A: Gen., 497 (2015) 31-41.

[14] J. Kugai, E.B. Fox, C. Song, Appl. Catal. A: Gen., 456 (2013) 204-214.

[15] M. Fernández-García, J.C. Conesa, A. Clotet, J.M. Ricart, N. López, F. Illas, J. Phys. Chem. B, 102 (1998) 141-147.

[16] K.A. Guy, H. Xu, J.C. Yang, C.J. Werth, J.R. Shapley, J. Phys. Chem. C, 113 (2009) 8177-8185.

[17] L. Liu, Z. Yao, Y. Deng, F. Gao, B. Liu, L. Dong, ChemCatChem, 3 (2011) 978-989.

[18] J. Kugai, T. Moriya, S. Seino, T. Nakagawa, Y. Ohkubo, H. Nitani, T. Akita, Y. Mizukoshi, T.A. Yamamoto, Chem. Eng. J., 223 (2013) 347-355.

[19] H.L. Tierney, A.E. Baber, E.C.H. Sykes, J. Phys. Chem. C, 113 (2009) 7246-7250.

[20] A.M. Molenbroek, S. Haukka, B.S. Clausen, J. Phys. Chem. B, 102 (1998) 10680-10689.

[21] J. Batista, A. Pintar, J.P. Gomilšek, A. Kodre, F. Bornette, Appl. Catal. A: Gen., 217 (2001) 55-68.

[22] M. Fernandez-Garcia, J.A. Anderson, G.L. Haller, J. Phys. Chem., 100 (1996) 16247-16254.

[23] S. Li, D. Cheng, X. Qiu, D. Cao, Electrochim. Acta, 143 (2014) 44-48.

[24] B.L. Gustafson, P.S. Wehner, Appl. Surf. Sci., 52 (1991) 261-270.

[25] S.Z. Hu, L. Scudiero, S. Ha, Electrochem. Commun., 38 (2014) 107-109. 
[26] P. Benito, M. Gregori, S. Andreoli, G. Fornasari, F. Ospitali, S. Millefanti, M.S. Avila, T.F. Garetto, S. Albonetti, Catal. Today, 246 (2015) 108-115.

[27] S. Sitthisa, T. Pham, T. Prasomsri, T. Sooknoi, R.G. Mallinson, D.E. Resasco, J. Catal., 280 (2011) $17-27$.

[28] K. Sasaki, H. Naohara, Y.M. Choi, Y. Cai, W.F. Chen, P. Liu, R.R. Adzic, Nat. Commun., 3 (2012) 1115 .

[29] A.B. Hungria, A. Iglesias-Juez, A. Martinez-Arias, M. Fernandez-Garcia, J.A. Anderson, J.C. Conesa, J. Soria, J. Catal., 206 (2002) 281-294.

[30] A. Renouprez, K. Lebas, G. Bergeret, J. Molecular Catal. A: Chem., 120 (1997) 217-225.

[31] S. Lambert, B. Heinrichs, A. Brasseur, A. Rulmont, J.P. Pirard, Appl. Catal. A: Gen., 270 (2004) 201-208.

[32] L. Wang, J.J. Zhai, K. Jiang, J.Q. Wang, W.B. Cai, Int. J. Hydrogen Energy, 40 (2015) 1726-1734.

[33] J. Kugai, J.T. Miller, N. Guo, C.S. Song, Appl. Catal. B: Environ., 105 (2011) 306-316.

[34] J. Kugai, T. Moriya, S. Seino, T. Nakagawa, Y. Ohkubo, H. Nitani, T.A. Yamamoto, Catal. Lett., (2013).

[35] T. Uchiyama, H. Yoshida, Y. Kuwauchi, S. Ichikawa, S. Shimada, M. Haruta, S. Takeda, Angew. Chem. Int. Ed., 50 (2011) 10157-10160.

[36] K. Kinoshita, J Electrochem. Soc., 137 (1990) 845-848.

[37] J. Perez, E.R. Gonzalez, E.A. Ticianelli, Electrochim. Acta, 44 (1998) 1329-1339.

[38] A. Gamez, D. Richard, P. Gallezot, F. Gloaguen, R. Faure, R. Durand, Electrochim. Acta, 41 (1996) 307-314.

[39] Y. Takasu, N. Ohashi, X.G. Zhang, Y. Murakami, H. Minagawa, S. Sato, K. Yahikozawa, Electrochim. Acta, 41 (1996) 2595-2600. 


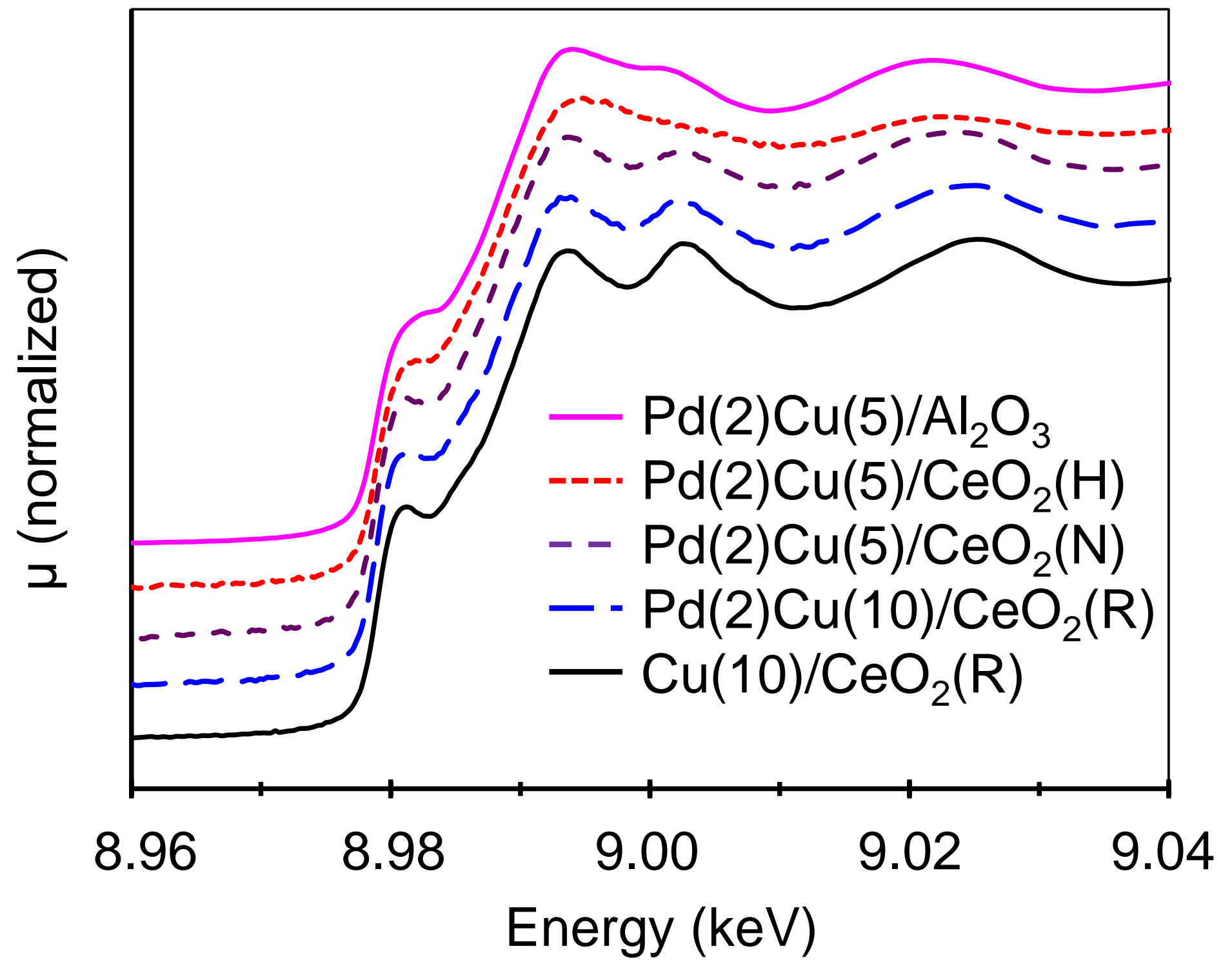

Fig. $1 \mathrm{Cu}$ K-edge XANES of the catalysts treated in $\mathrm{H}_{2}$ at $260^{\circ} \mathrm{C}$ and cooled to R.T. in $\mathrm{He}$ 


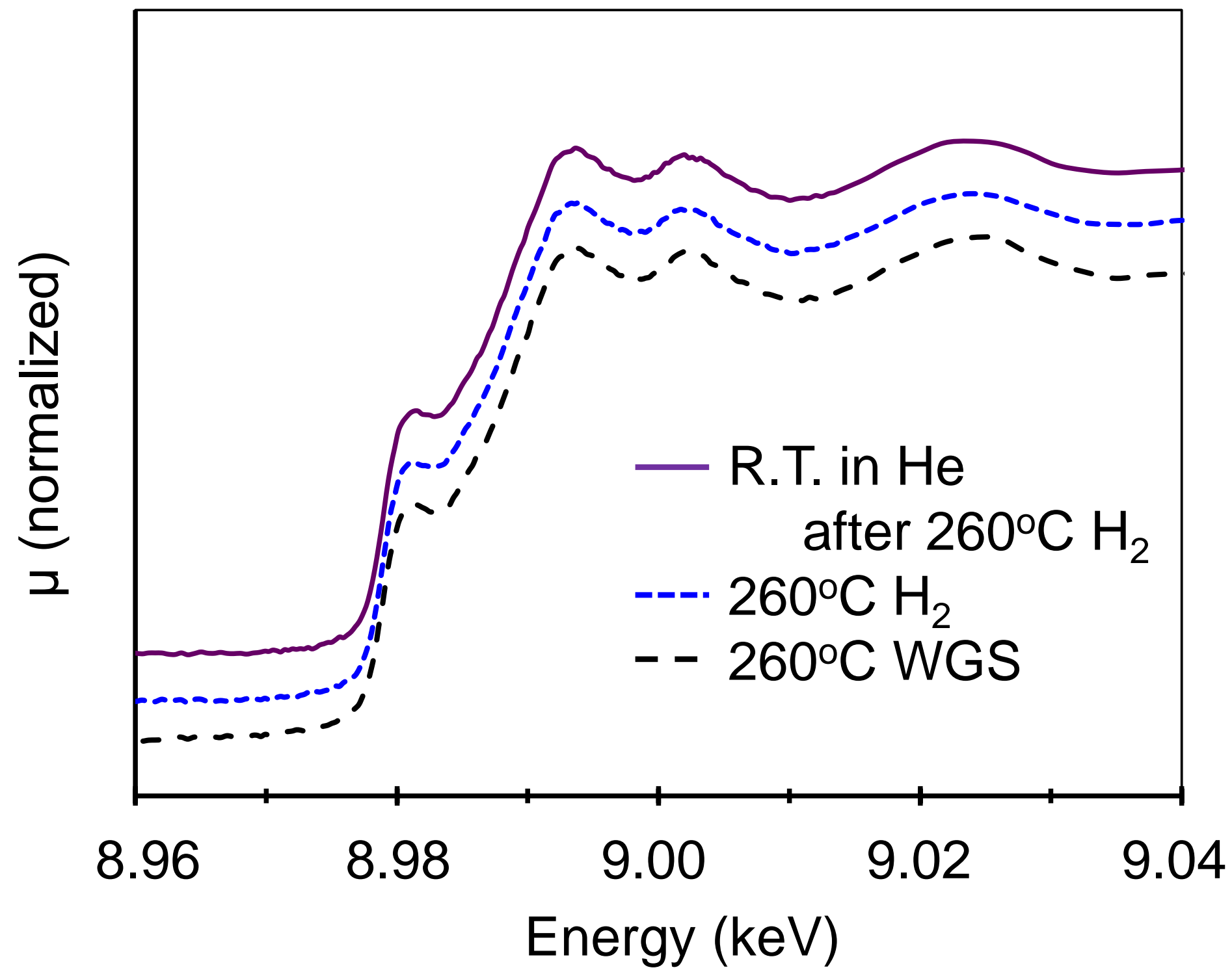

Fig. 2 Cu K-edge XANES of $\mathrm{Pd}(2) \mathrm{Cu}(10) / \mathrm{CeO}_{2}(\mathrm{R})$ catalysts treated in various conditions 


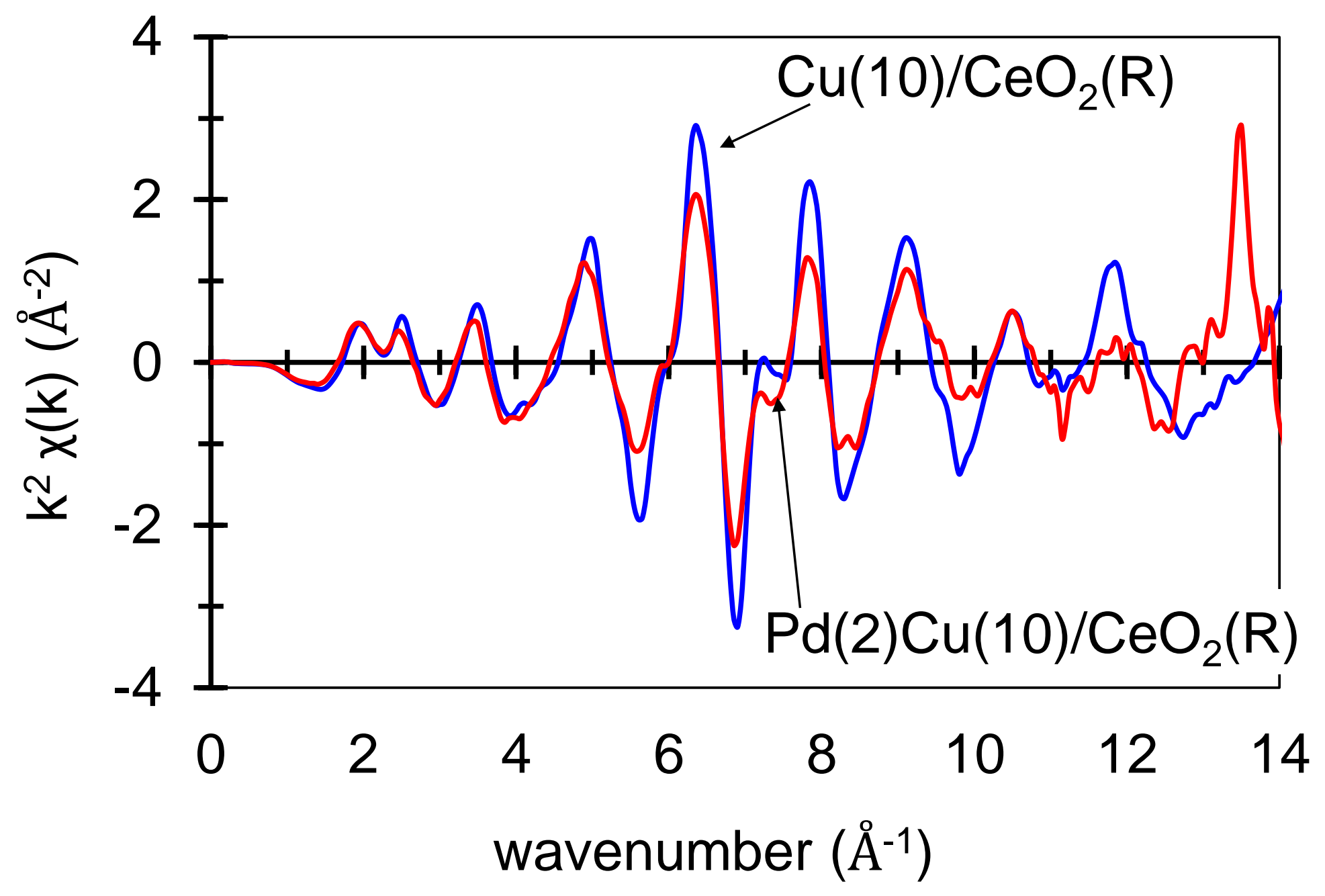

Fig. 3 Cu K-edge EXAFS oscillations in $\mathrm{k}$ space ( $\mathrm{k}^{2}$-weighting) of $\mathrm{Cu}(10) / \mathrm{CeO}_{2}(\mathrm{R})$ and $\mathrm{Pd}(2) \mathrm{Cu}(10) / \mathrm{CeO}_{2}(\mathrm{R})$ catalysts 


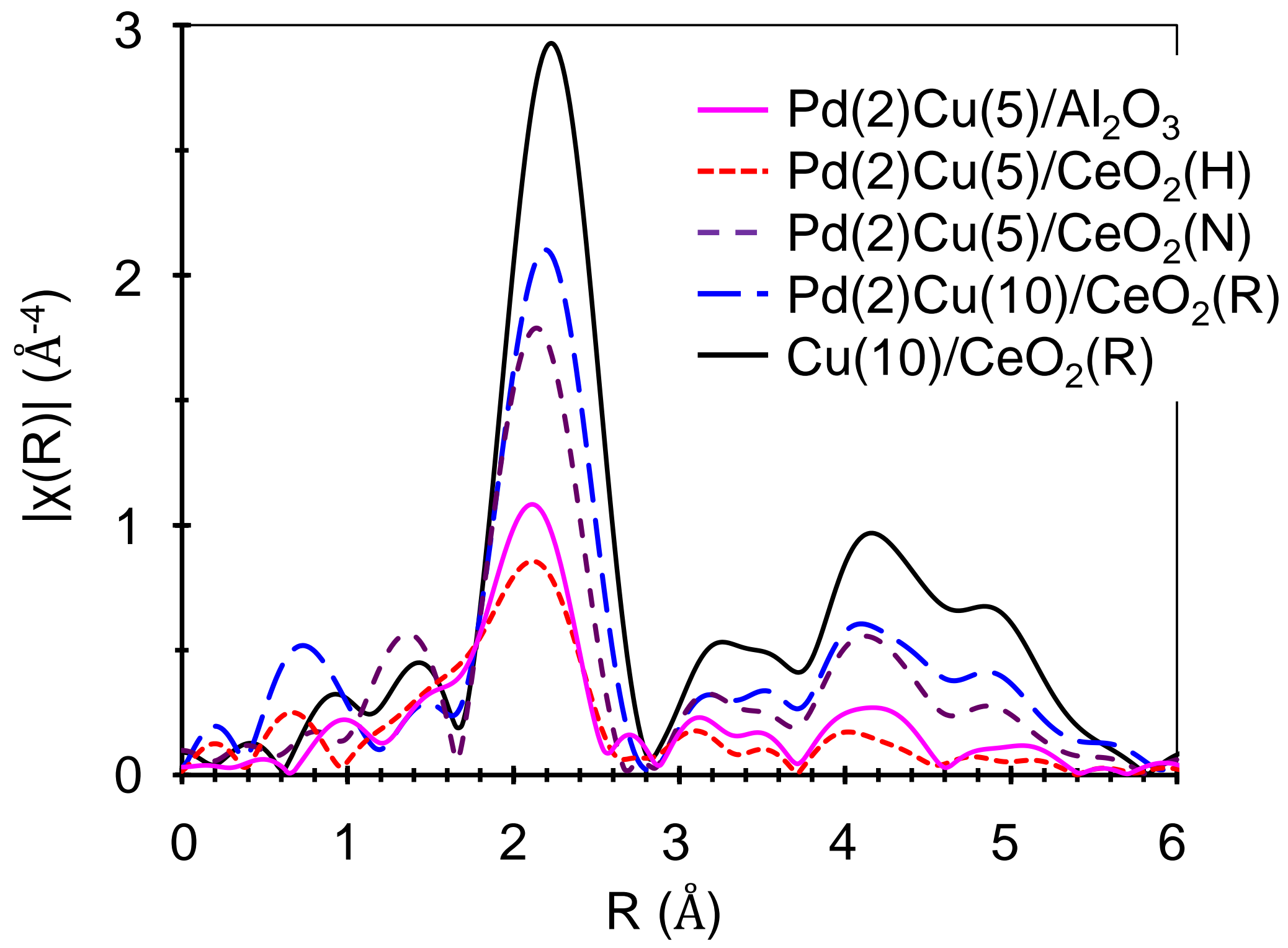

Fig. 4 Fourier transform of Cu K-edge EXAFS of the catalysts treated in $\mathrm{H}_{2}$ at $260^{\circ} \mathrm{C}$ and cooled to R.T. in $\mathrm{He}$ 


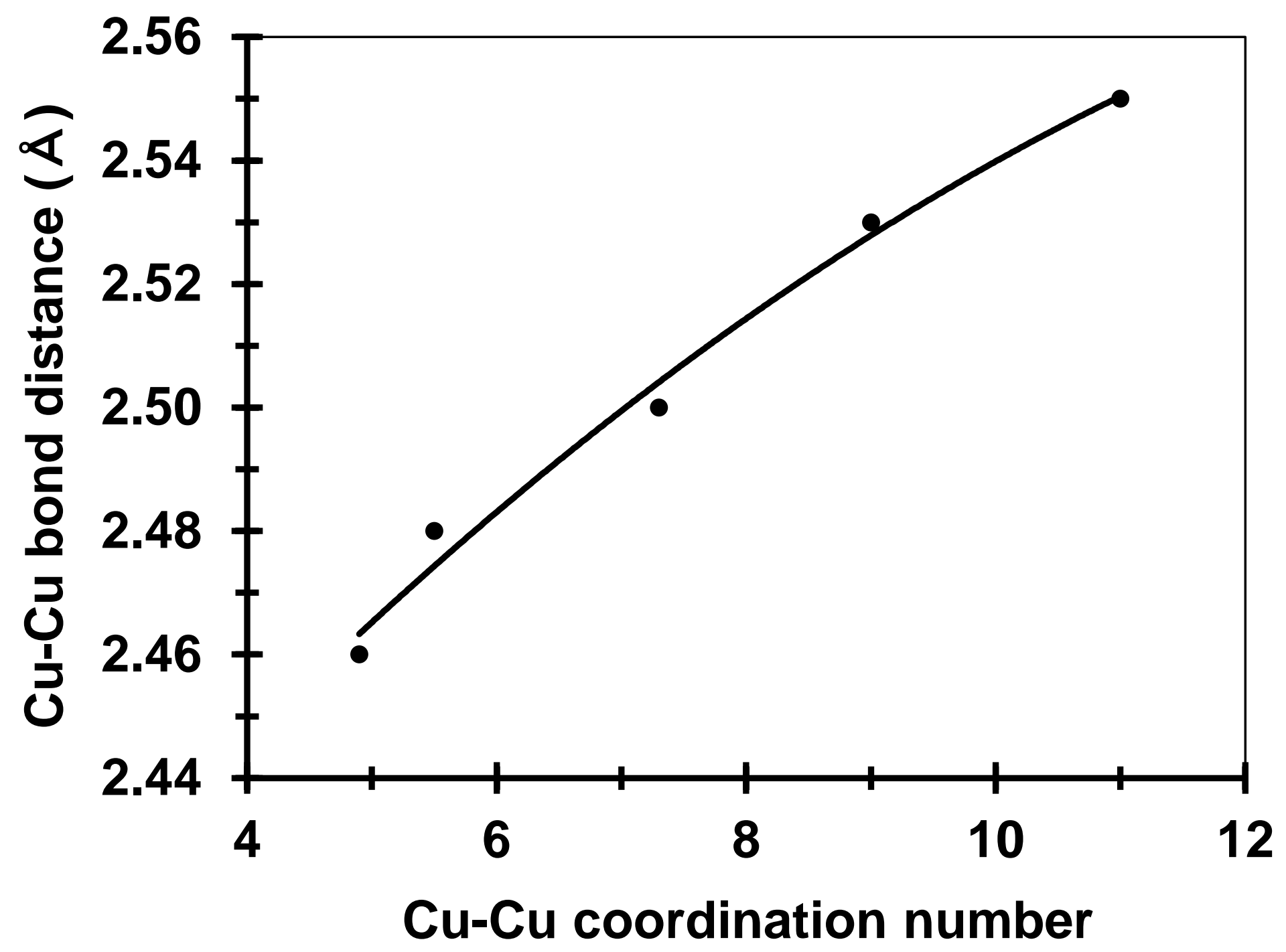

Fig. 5 Correlation between $\mathrm{Cu}-\mathrm{Cu}$ coordination number and $\mathrm{Cu}-\mathrm{Cu}$ bond distance in $\mathrm{Pd}-\mathrm{Cu}$ catalysts 


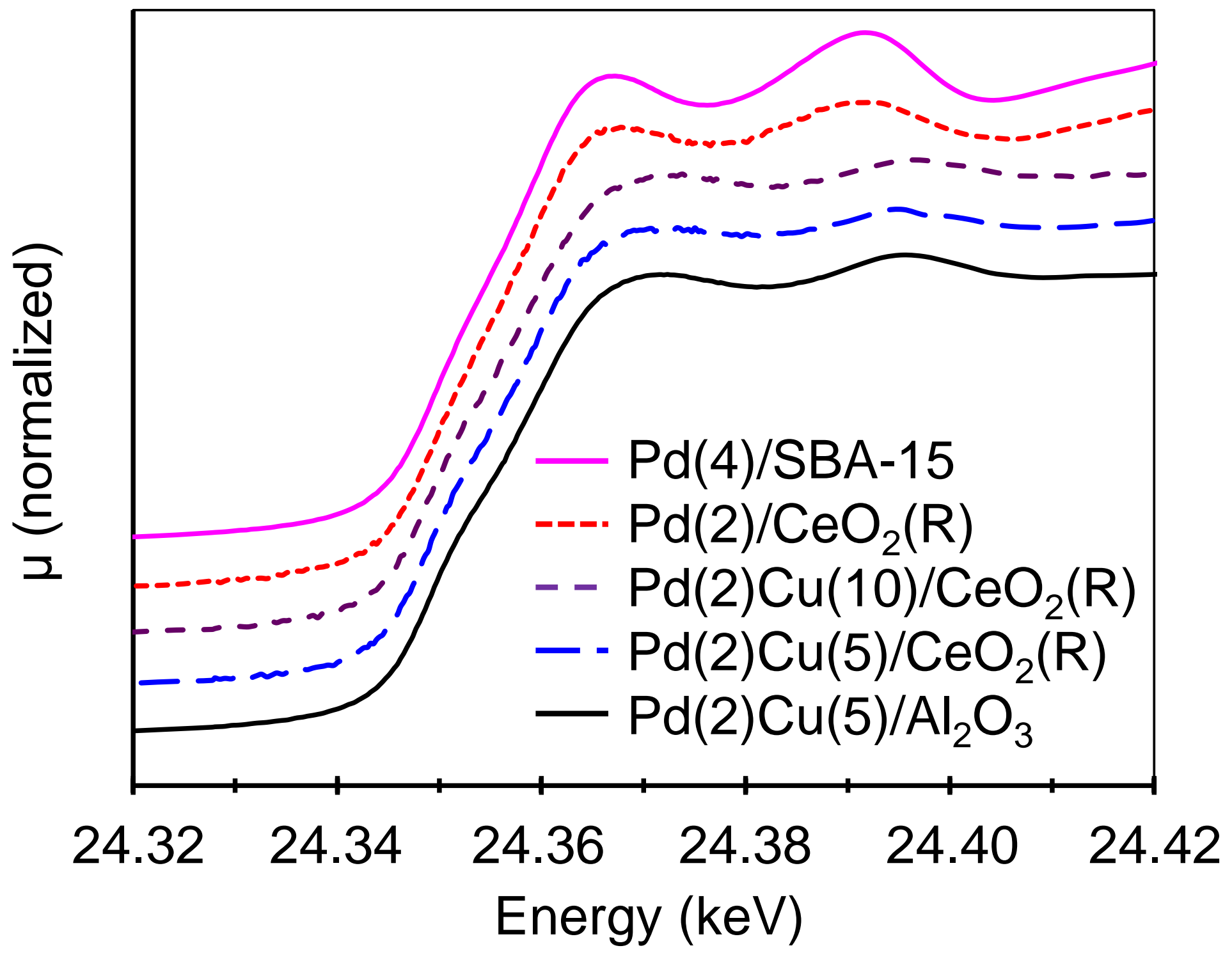

Fig. 6 Pd K-edge XANES of the catalysts treated in $\mathrm{H}_{2}$ at $260^{\circ} \mathrm{C}$ and cooled to R.T. in $\mathrm{He}$ 


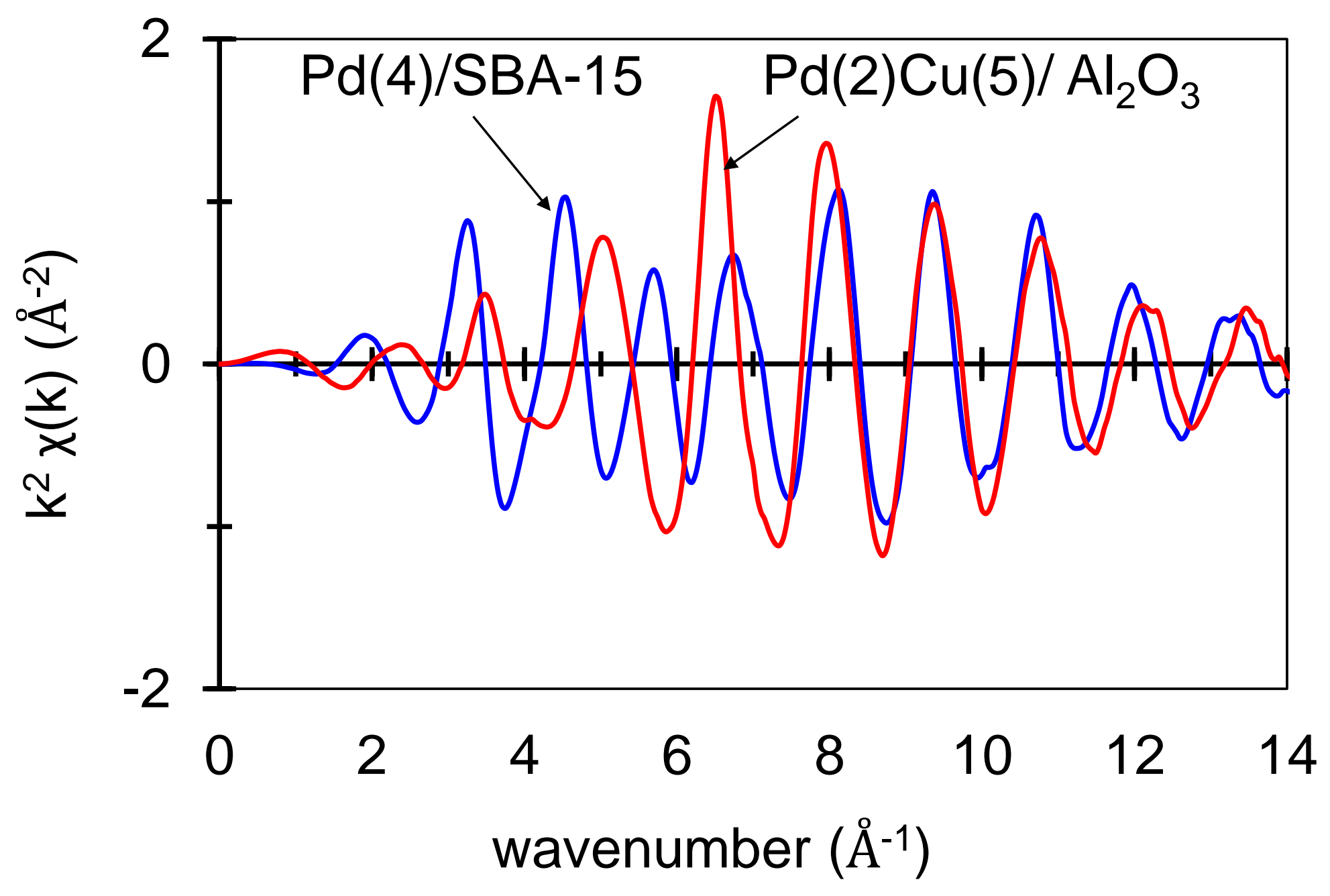

Fig. 7 Pd K-edge EXAFS oscillations in $\mathrm{k}$ space ( $\mathrm{k}^{2}$-weighting) of $\mathrm{Pd}(4) / \mathrm{SBA}-15$ and $\mathrm{Pd}(2) \mathrm{Cu}(5) / \mathrm{Al}_{2} \mathrm{O}_{3}$ catalysts 


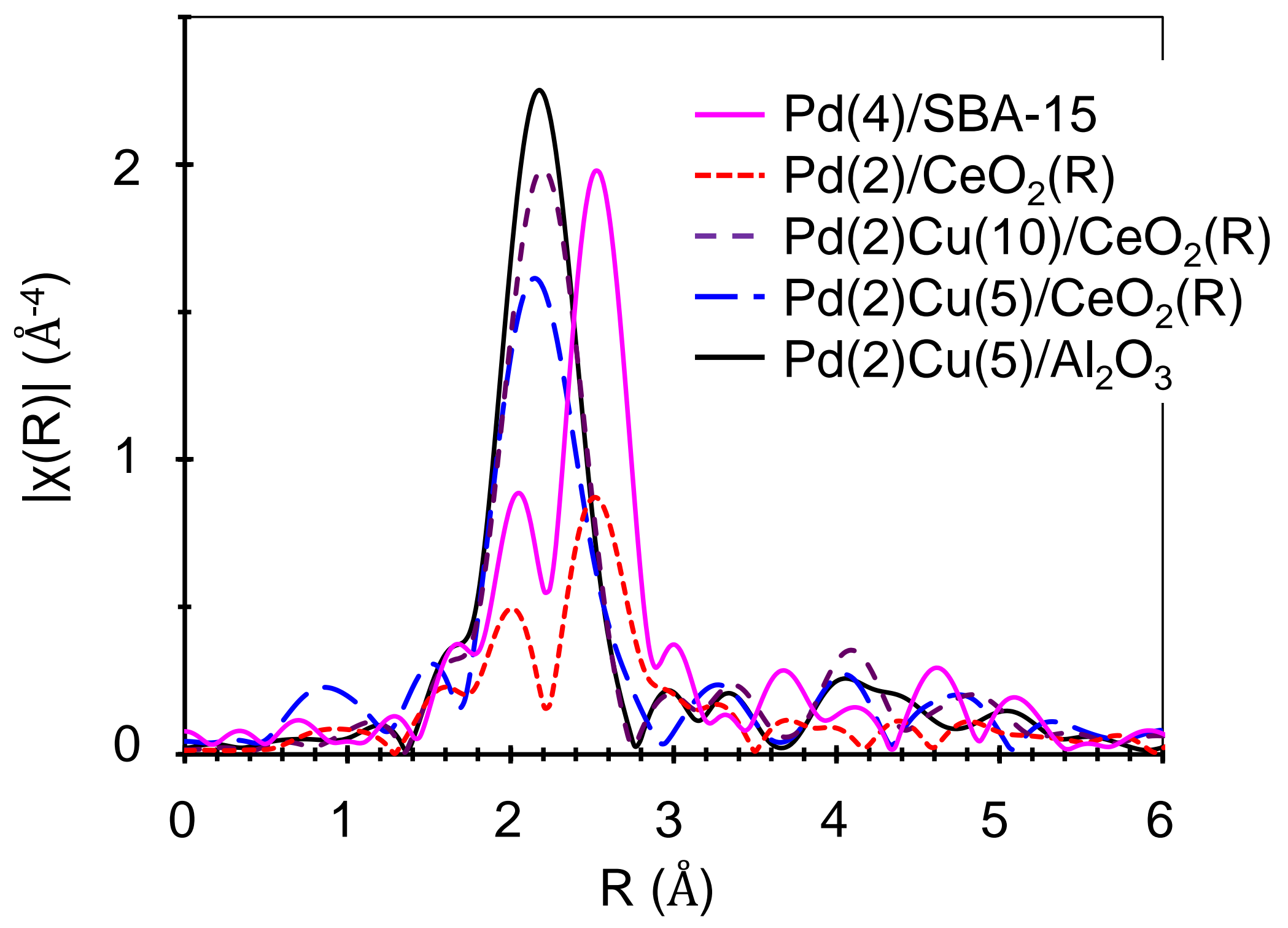

Fig. 8 Fourier transform of Pd K-edge EXAFS of the catalysts treated in $\mathrm{H}_{2}$ at $260^{\circ} \mathrm{C}$ and cooled to R.T. in $\mathrm{He}$ 


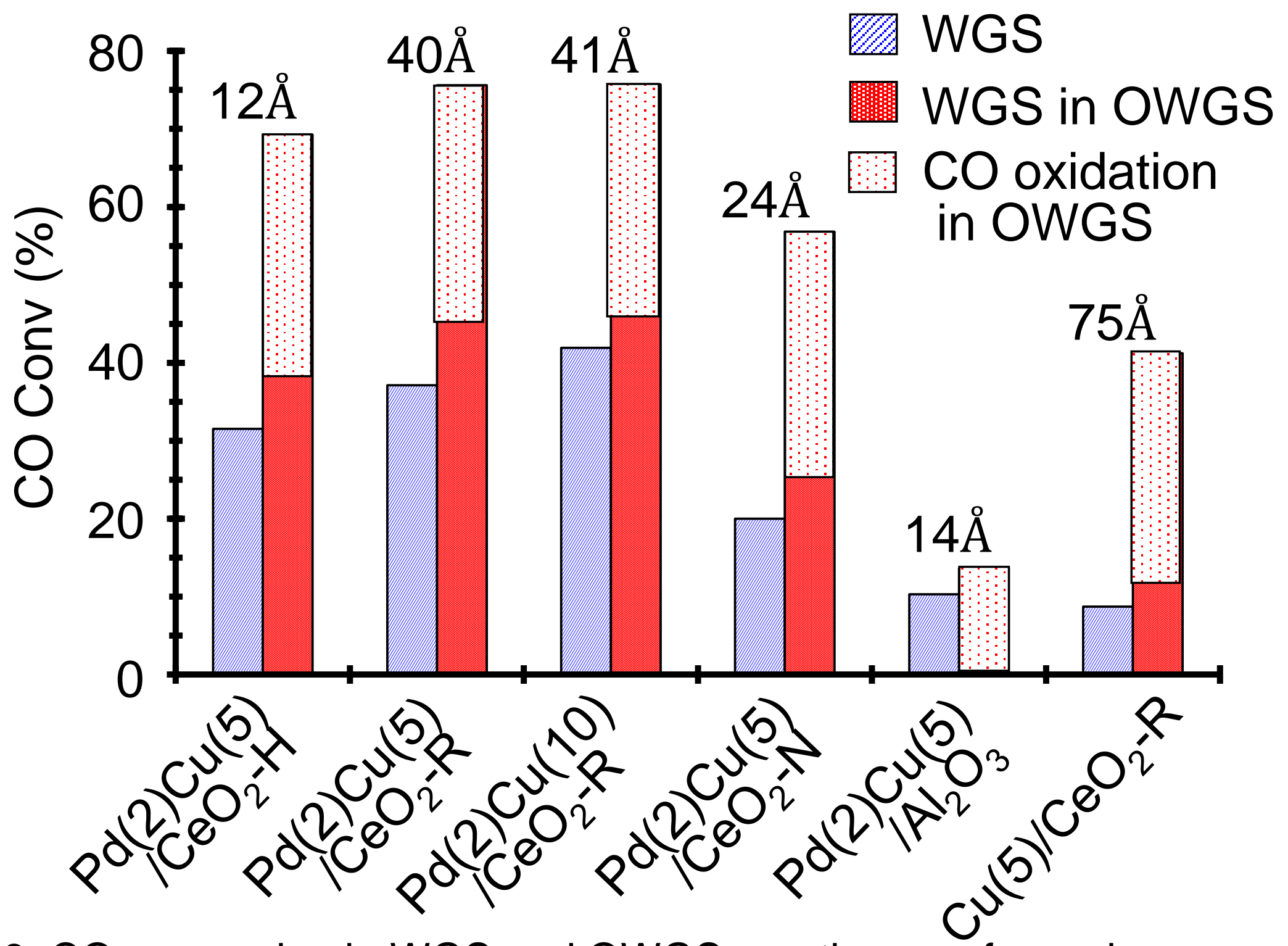

Fig. 9 CO conversion in WGS and OWGS reactions performed on $\mathrm{Pd}-\mathrm{Cu}$ catalysts on various supports.

Feed: $9.7 \% \mathrm{CO} / 22.8 \% \mathrm{H}_{2} \mathrm{O} / 6.3 \% \mathrm{CO}_{2} / 37.9 \% \mathrm{H}_{2} / 6.9 \% \mathrm{~N}_{2}$ or Air / argon. Temperature: $260^{\circ} \mathrm{C}, \mathrm{GHSV}: 64,400 \mathrm{~h}^{-1}$ (dry) 
Graphical abstract

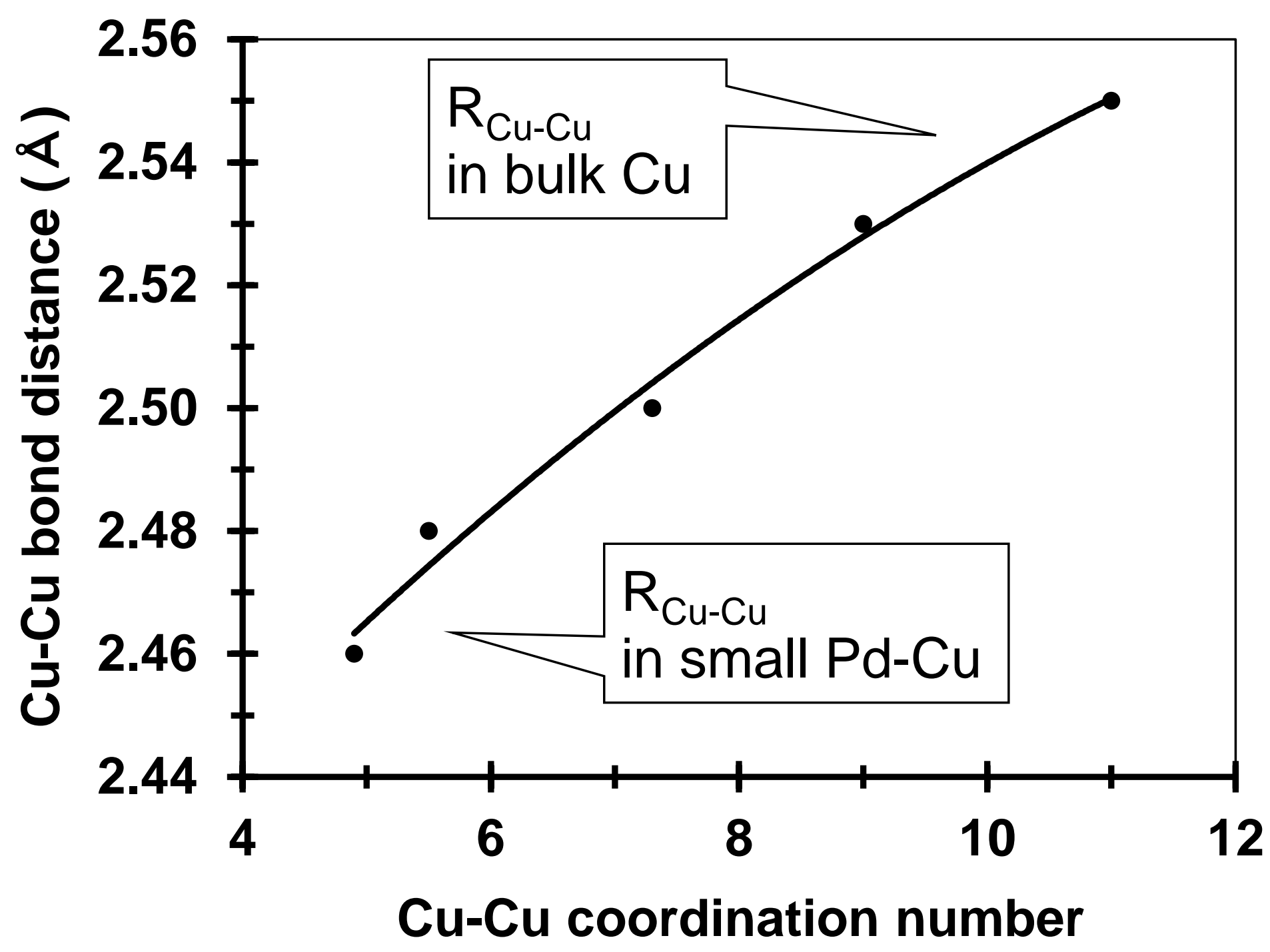

